\title{
PENGARUH PENDIDIKAN KESEHATAN (QUANTUM LEARNING) TERHADAP PENGETAHUAN TENTANG MAKANAN JAJANAN PADA SISWA-SISWI DI SIDOREJO 3 KECAMATAN ARUT SELATAN
}

\author{
${ }^{1}$ Eny Lestari,S.Kep.,Ners.,M.M.R.S \\ ${ }^{1}$ STIkes Borneo Cendekia Medika Pangkalan Bun \\ 1enylestari@gmail.com
}

\begin{abstract}
ABSTRAK
Keberadaan makanan jajanan anak sekolah perlu mendapat perhatian khusus. Pengetahuan makanan dan kesehatan sangat penting untuk dipelajari karena karena pengetahuan tentang makanan dan kesehatan adalah faktor internal yang mempengaruhi konsumsi makanan jajanan. Tujuan penelitian ini adalah pengaruh pendidikan kesehatan (quantum learning) terhadap pengetahuan tentang makanan jajanan pada siswa-siswi. Jenis penelitian yang digunakan dalam penelitian ini adalah Queasy Experiment (pre dan post test design). Jumlah sampel sebanyak 124 responden yang diambil dengan rumus Simple random sampling. Data diperoleh dengan menggunakan kuesioner dan dianalisis secara statitiska menggunakan uji Wilcoxon. Dari hasil uji statistik didapatkan pengetahuan pada saat pre test sebagian besar responden kelompok perlakuan memiliki pengetahuan cukup yaitu 31 responden $(50 \%)$ dan kelompok kontrol pengetahuan cukup yaitu 30 responden $(48,4 \%)$. post test sebagian besar responden kelompok perlakuan memiliki pengetahuan baik yaitu 41 responden $(66,1 \%)$. Dan kelompok kontrol memiliki pengetahuan cukup yaitu 30 responden $(48,4 \%)$. (Uji Wilcoxon $=0,01$ ) Ada pengaruh penyuluhan kesehatan terhadap pengetahuan tentang makanan jajanan pada siswa-siswi di SDN Sidorejo 3 Kecamatan Arut Selatan Kabupaten Kotawaringin Barat Tahun 2016. Sehubungan dengan hasil penelitian ini diharapkan mengikuti penyuluhan yang telah diberikan oleh pihak sekolah.
\end{abstract}

Kata Kunci : Pendididikan Kesehatan, Tingkat Pengetahuan

\author{
THE EFFECT OF HEALTH EDUCATION (QUANTUM LEARNING) TOWARDS \\ KNOWLEDGE OF FOOD SERVICES IN STUDENTS IN SIDOREJO 3 KECAMATAN ARUT \\ SELATAN
}

\begin{abstract}
The existence of snacks for school children needs special attention. Knowledge of food and health is very important to learn because because knowledge of food and health is an internal factor that influences the consumption of snacks. The purpose of this study is the effect of health education (quantum learning) on the knowledge of food snacks on students. This type of research used in this study is Queasy Experiment (pre and post test design). The total sample of 124 respondents were taken by the simple random sampling formula. Data were obtained using a questionnaire and statistically analyzed using the Wilcoxon test. From the statistical test results obtained knowledge at the time of the pre-test most respondents in the treatment group had sufficient knowledge of 31 respondents (50\%) and the control group of knowledge was sufficient that was 30 respondents (48.4\%). post test most respondents in the treatment group had good knowledge, 41 respondents (66.1\%). And the control group had sufficient knowledge, namely 30 respondents $(48.4 \%)$. (Wilcoxon Test $=0.01)$ There is an
\end{abstract}


influence of health education on knowledge about food for snacks on students at SDN Sidorejo 3, Arut Selatan District, Kotawaringin Barat Regency in 2016. In connection with the results of this study are expected to follow counseling that has been given by the school.

\section{Keywords: Health Education, Knowledge Level}

\section{PENDAHULUAN}

Kebiasaaan makan merupakan salah satu faktor yang mempengaruhi status gizi anak. Kebiasaan anak senang jajan dapat berdampak buruk sebab banyak makanan jajanan yang tidak aman dan tidak sehat beredar. Mengonsumsi makanan jajanan yang tidak aman dan tidak sehat dapat menyebabkan anak terkena penyakit dan dapat menurunkan status gizi anak. Makanan yang aman, bermutu dan bergizi seimbang tidak terlepas dari faktor keamanan pangan. Berbagai kasus gangguan kesehatan manusia akibat mengonsumsi pangan yang tercemar oleh cemaran fisik, biologis, dan kimia telah terjadi diberbagai daerah dan bahkan tergolong sebagai Kejadian Luar Biasa (KLB). Kasus keamanan pangan yang banyak dijumpai adalah keracunan pangan, dimana salah satu sumber pangan yang menyebabkan keracunan adalah makanan jajanan.

Pengetahuan makanan dan kesehatan sangat penting untuk dipelajari karena pengetahuan tentang makanan dan kesehatan adalah faktor internal yang mempengaruhi konsumsi makanan jajanan. Untuk mengurangi perilaku jajan sembarangan pada anak sekolah dasar terhadap makanan jajanan yang tidak sehat dan tidak aman diperlukan kepedulian terhadap keamanan makanan jajanan dari bebagai pihak seperti guru, orang tua, dan pedagang. Disinilah pentingnya sosialisasi keamanan makanan jajanan khususnya pada anak sekolah yang notabene merupakan golongan usia pertumbuhan yang seharusnya mengonsumsi makanan jajanan sehat.

\section{METODOLOGI PENELITIAN}

Jenis penelitian yang digunakan dalam penelitian ini adalah Queasy Experiment (pre dan post test design). Polpulasi penelitian ini adalah seluruh siswa-siswi SDN Sidorejo 3 Kecamatan Arut Selatan Kabupaten Kotawaringin Barat dengan jumlah sample adalah sebanyak 64 responden dengan teknik sampling Random sampling (Probability sampling). Analisis yang digunakan adalah uji dependent $t$ Test (paired $t$ Test).

\section{HASIL PENELITIAN}

\section{A. Data umum}

Besar responden berumur 6-8 tahun didalam responden ini adalah sebanyak 68 responden (19.4\%), sebagian besar responden dalam penelitian ini adalah kelas I-III yaitu sebanyak 64 responden (18.5\%).

B. Data khusus

Sebagian besar responden kelompok perlakuan memiliki pengetahuan cukup yaitu 31 responden (50\%). Dan kelompok kontrol memiliki pengetahuan cukup yaitu 30 responden $(48,4 \%)$. sebagian besar responden kelompok perlakuan memiliki pengetahuan baik yaitu 41 responden $(66,1 \%)$. Dan kelompok 
kontrol memiliki pengetahuan cukup yaitu 30 responden $(48,4 \%)$. Hasil uji statistik wilcoxon antara kelompok perlakuan dan kelompok kontrol didapatkan nilai $\rho$ (sig.2-tailed ) = 0,01 untuk uji dua sisi. Karena pada kasus ini adalah uji satu sisi maka probabilitas menjadi $0,01 / 2=0,005$, $0,005<0,05$ berarti hasil uji signifikan secara statistik dengan demikian dapat tidak dapat menerima Hipotesis null sehingga ada perbedaan antara kelompok perlakuan dan kelompok control, yang artinya ada pengaruh ada pengaruh pendidikan kesehatan terhadap pengetahuan tentang makanan jajanan pada siswa-siswi di SDN Sidorejo 3 Kecamatan Arut Selatan Kabupaten Kotawaringin Barat Tahun 2016.

\section{PEMBAHASAN}

Berdasarkan uji untuk melihat adanya pengaruh dengan menggunakan uji statistik wilcoxon. Hasil yang didapat Ada pengaruh pendidikan kesehatan dengan pengetahuan tentang makanan jajanan pada siswa-siswi di SDN Sidorejo 3 Kecamatan Arut Selatan Kabupaten Kotawaringin Barat Tahun 2016.

Tingkat pengetahuan responden sebenarnya dapat dipengaruhi beberapa faktor yaitu usia dan informasi. Sebagian besar responden berusia 8 tahun yang dimana responden membutuhkan seseorang yang dapat dipercaya untuk memberikan informasi tentang pendidikan kesehatan. Responden mengalami perubahan setelah diberikan intervensi pembelajaran pendidikan kesehatan. Secara konsep, pendidikan kesehatan adalah upaya untuk mempengaruhi, dan atau mengajak oranglain, baik individu, kelompok, atau masyarakat, agar melaksanakan perilaku hidup sehat.

\section{KESIMPULAN DAN SARAN}

\section{A. Kesimpulan}

Pengetahuan pada saat pre test sebagian besar responden kelompok perlakuan memiliki pengetahuan cukup yaitu 31 responden (50\%). Dan kelompok kontrol memiliki pengetahuan cukup yaitu 30 responden (48,4\%). Pengetahuan pada saat post test sebagian besar responden kelompok perlakuan memiliki pengetahuan baik yaitu 41 responden $(66,1 \%)$. Dan kelompok kontrol memiliki pengetahuan cukup yaitu 30 responden (48,4\%). Ada pengaruh penyuluhan kesehatan terhadap pengetahuan tentang makanan jajanan pada siswa-siswi di SDN Sidorejo 3 Kecamatan Arut Selatan Kabupaten Kotawaringin Barat Tahun 2016.

\section{B. Saran}

Penelitian ini diharapkan dapat menjadi bahan masukan bagi pihak sekolah dalam memberikan penyuluhan tentang makan jajanan pada siswa-siswinya dan diharapkan dapat menjadi bahan masukan bagi anak-anak dalam menyikapi hal-hal yang berhubungan dengan pendidikan kesehatan.

\section{DAFTAR PUSTAKA}

Haryanto.(2004). Status Gizi dan Tingkat Kesegaran Jasmani Anak dari Keluarga Pra-Sejahtera pada Sekolah Lanjutan Tingkat Pertama 
Negeri Se-Kecamatan Larangan Kabupaten Brebes Tahun 2004/2005. Skripsi. Fakultas Ilmu Olahraga Universitas Negeri Semarang.

Khomsan A.(2010). Pangan dan Gizi untuk Kesehatan. Jakarta: PT. Raja grafindo Persada.

Suhardjo.(2006). Pangan, Gizi, dan Pertanian. Jakarta. Universitas. Indonesia.

Tjitarsa I. (2007).Pendidikan Kesehatan: Pedoman Pelayanan Kesehatan Dasar. Bandung: Penerbit ITB dan Penerbit Universitas Udayana.

dinkes.indramayukab.go.id/ diakses tanggal 18 November 2014.

Notoatmodjo, s.(2007).Pendidikan dan perilaku kesehatan, Jakarta : PT Rineka Cipta.

De Porter, Bobbi, dan Hernacki, Mik.(2007). Quantum

Learning. Diterjemahkan oleh Alwiyah Adurrahman. Bandung: Kaifa PT Mizan Pustaka.

Azwar.(2007).Reliabilitas dan Validitas. Yogyakarta. Pustaka Pelajar.

Azrul.(2007).Pengantar Administrasi Kesehatan. Jakarta: Bina Rupa Aksara.

Saiders, Raini Rahmania.(2011).Laporan Penyuluhan jajan. diakses tanggal 15 November 2014.

Irianto, Kus dan Kusno Waluyo.( 2007).Vitamin, air, dan oksigen merupakan makanan pelindung dan pengatur tubuh. In: Gizi dan Pola Hidup Sehat.Bandung: Yrama Widya.

Tampubolon, F.(2009).Pengaruh Media Visual Poster dan Leaflet Makanan
Sehat terhadap Perilaku Konsumsi Makanan Jajanan Pelajar Kelas Khusus SMA Negeri 1 Panyabungan Kabupaten Mandailing Natal. Skripsi Gizi Kesehatan Masyarakat USU. Medan.

Aprillia, Bondika Ariandani. (2011). Faktor yang Berhubungan dengan Pemilihan Makanan Jajanan pada Anak Sekolah Dasar. Skripsi, Fakultas Kedokteran Universitas Diponegoro, Semarang.

Nursalam. Konsep dan Penerapan Metodologi Penelitian Ilmu Keperawatan, Jakarta : Salemba Medika.2008

Erfandi, (2009) Pengetahuan dan faktorfaktor yang mempengaruhi. [Internet], Tersedia dalam: http://forbetterhealth.wordperss.com/ 2009/04/19 Pengetahuan-dan-faktorfaktor-yang-mempengaruhi diakses tanggal 18 November 2014. 